\title{
Field trials of GM trees in the USA: activity and regulatory developments
}

\author{
Steven H Strauss ${ }^{*}$, Venkatesh Viswanath \\ From IUFRO Tree Biotechnology Conference 2011: From Genomes to Integration and Delivery \\ Arraial d Ajuda, Bahia, Brazil. 26 June - 2 July 2011
}

Field trials are extremely important for all facets of research, breeding, and biotechnology. Tree physiology is distinctively different in greenhouses or growth chambers vs. field environments. Thus, results from non-field environments can be very misleading with respect to identification of promising biotechnologies and elite varieties. Large regulatory impediments to conduct of field tests of genetically modified (GM) trees will therefore tend to stifle scientific and technological development. This appears to be the case for genetically modified trees, where regulatory burdens to conducting field tests have grown in stringency in the USA and elsewhere in recent years $[1,2]$. Here, we present the record of recent field trials and some new regulatory developments in the USA.

\section{Overview of field trials in the USA}

Information Systems for Biotechnology (ISB) [3] maintains an easily used database of GM crop data in the United States. There have been nearly 600 field trials (including both "acknowledgments" and "permits") conducted since 1989, with a five-fold increase occurring in 2000-2009 compared with 1990-1999 (Figure 1).

Fifteen different genera have been tested, including Populus, Pinus, Eucalyptus, and Malus, with the first two accounting for approximately $60 \%$ of all field trials (Figure 2). Marker genes and tolerance to biotic stresses were the two most common research objectives. Private companies carried out $60 \%$ of field trials, and their activity has grown dominant in recent years.

Currently, there are more than sixty field trials covering eleven different genera, with Populus accounting for $35 \%$ of all field trials. Eucalyptus, Liquidambar, and Malus together account for another $37 \%$ of trials. Other genera being tested include Castanea (American chestnut), Pinus, Ulmus (American elm), Prunus, Musa, Citrus, and Juglans. Forty field trials are being conducted by private companies, with ArborGen alone accounting for 36 of the 40 active field trials. Cornell University, North Carolina State University, Oregon State University, Purdue University, the United States Department of Agriculture (ARS) and the University of California, Davis are among the public institutions currently conducting field trials. One of ArborGen's field trials with cold tolerant Eucalyptus covers 197.2 acres. This is the largest current field trial in terms of acres and is being conducted in six different states. In terms of research objectives of current trials, marker genes dominate in terms of frequency of trials, with modification of wood quality the next most common objective.

\section{Regulation of field trials in the USA}

In the USA, transgenic trees are regulated in the same manner as agricultural crops [4], using regulatory laws created prior to the development of transgenic biotechnology. The three agencies involved are the United States Department of Agriculture (USDA), which considers agricultural safety and economics; the Food and Drug Administration (FDA), which considers human and animal feed safety; and the Environmental Protection Agency (EPA), which considers pesticidal properties of transgenic organisms [5]. Regulations in the United States are perceived to be less stringent than those in Europe and Asia, however, a recent survey in the USA found that forest scientists-including breeders, biotechnologists, and ecologists-see regulations as major obstacles to field research and commercial development of GM trees [6].

* Correspondence: Steve.Strauss@oregonstate.edu

Department of Forest Ecosystems and Society, Oregon State University, 321 Richardson Hall, Corvallis, OR 97331, USA

(c) 2011 Strauss and Viswanath; licensee BioMed Central Ltd. This is an open access article distributed under the terms of the Creative 


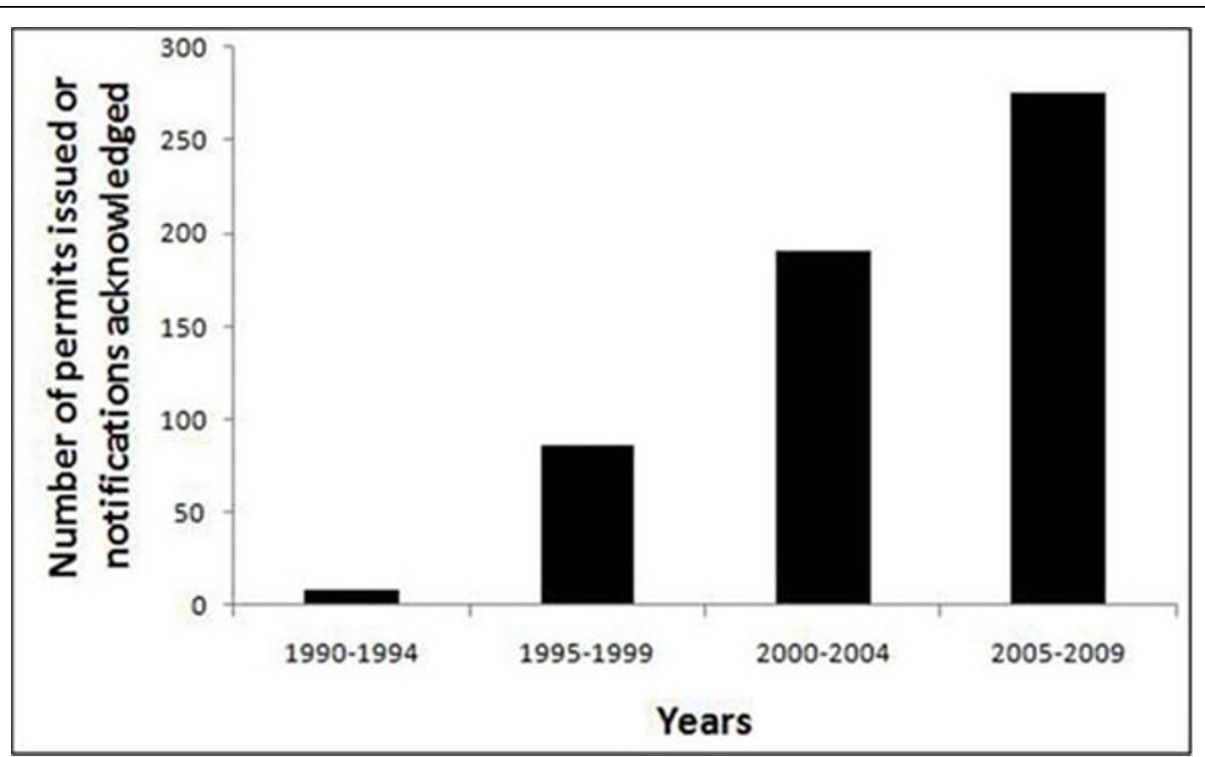

Figure 1 Total number of field trials with transgenic trees in the USA between 1990 and 2009.

\section{Recent regulatory developments}

A company known as Okanagan Specialty Fruits has taken the lead in the production of transgenic tree varieties produced by the insertion of cisgenes and intragenes [7]. Non-browning versions of established apple varieties were developed by the company by the silencing of the polyphenol oxidase gene. These apples have been named Arctic ${ }^{\mathrm{TM}}$ apples because of the color of their skin. The company has petitioned the Animal and
Plant Health Inspection Service (APHIS) for deregulation of the product in the USA [8].

Cold tolerant eucalyptus varieties were developed by ArborGen [9]. The company believes that these varieties would permit the planting of highly productive eucalypt hybrids for bioenergy and pup north of Florida in the USA. In May 2010, the USDA authorized a large scale flowering field trial of these trees, thus permitting the planting of nearly 260,000 trees over $\sim 300$ acres in

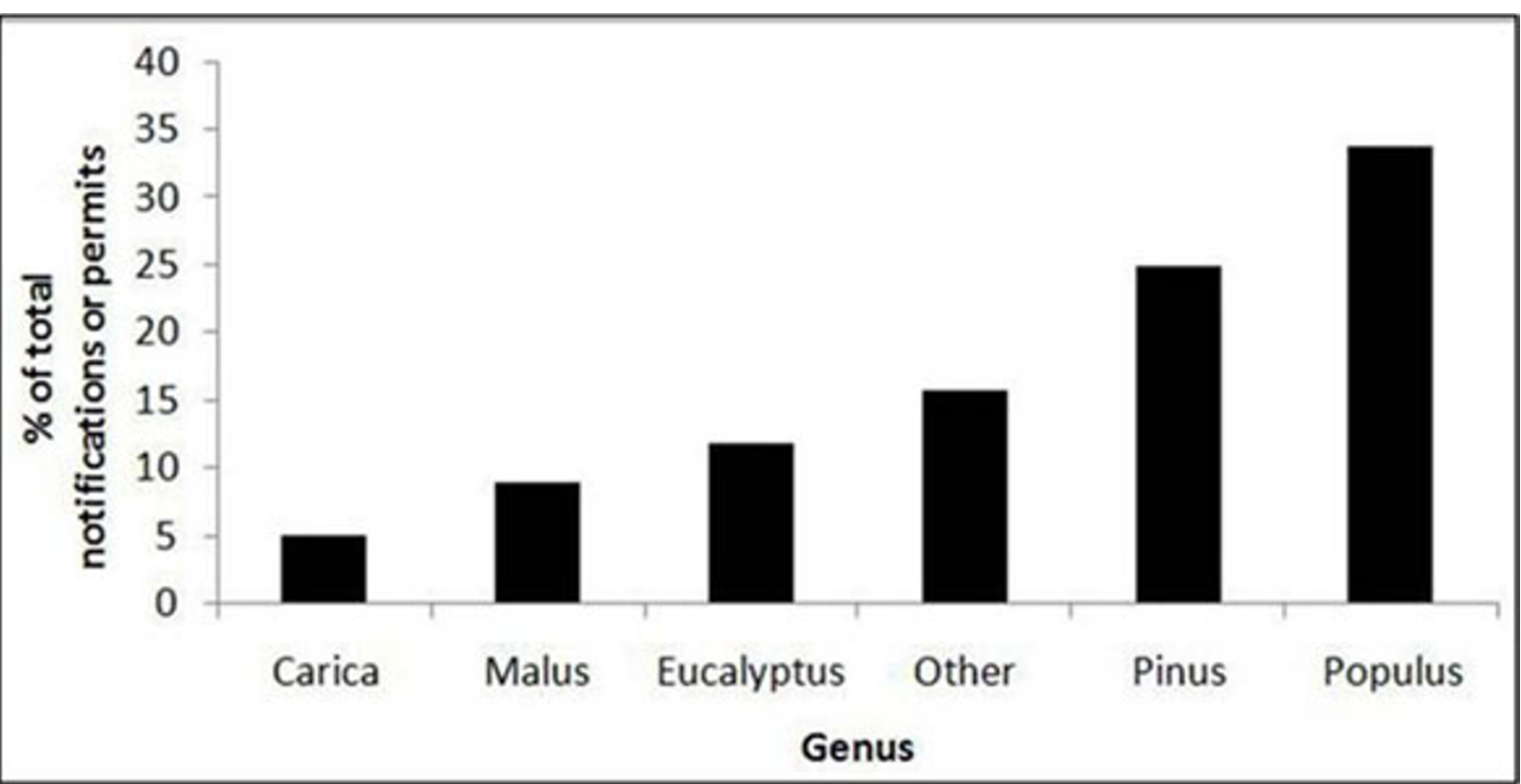

Figure 2 Major genera of transgenic trees in field trials in the USA, 1990 to present. 
7 states [10]. However, several environmental organizations filed a lawsuit against APHIS because they believed that APHIS performed an inadequate environmental analysis, thus violating the US National Environmental Policy Act (NEPA).

A new two year pilot project has recently been announced by APHIS [11]. Under the provisions of the new project-whose aim is to speed up the review process before deregulation of biotech crops-environmental assessments of transgenic crops will be conducted by companies themselves, or by contractors authorized by the USDA. Although USDA would still need to review and approve the analyses, critics of the new policy believe that it might lead to less stringent environmental analyses.

Published: 13 September 2011

\section{References}

1. Strauss SH, Tan H, Boerjan W, Sedjo R: Strangled at birth? Forest biotech and the Convention on Biological Diversity. Nature Biotechnology 2009, 27:519-527.

2. Strauss SH, Kershen DL, Bouton JH, Redick TP, Tan H, Sedjo R: Far-reaching deleterious impacts of regulations on research and environmental studies of recombinant-DNA modified perennial biofuel crops in the USA. BioScience 2010, 60:729-741.

3. Information Systems for Biotechnology: USDA field tests of GM cropsSearch the release data. 2011 [http://www.isb.vt.edu/search-release-data. aspx].

4. Harry DE, Strauss SH: Biotechnology and genetic engineering in forest trees. 2010 [http://www.agribiotech.info/details/Strauss\%20and\%20Harry\% 20Draft\%20Final\%2002\%20print.pdf].

5. McHughen A, Smyth S: US regulatory system for genetically modified [genetically modified organism (GMO), rDNA or transgenic] crop cultivars. Plant Biotechnol J 2007, 6:2-12

6. Strauss SH, Schmitt A, Sedjo R: Forest scientist views of regulatory obstacles to research and development of transgenic forest biotechnology. Journal of Forestry 2009, 107:350-357.

7. Okanagan Specialty Fruits: Non-browning apple. 2011 [http://www. okspecialtyfruits.com/ps-non-browning-apple.php].

8. Animal and Plant Health Inspection Service (APHIS): Petitions for nonregulated status pending. 2011 [http://www.aphis.usda.gov/ biotechnology/not_reg.html].

9. ArborGen: Freeze tolerant eucalyptus. 2011 [http://www.arborgen.us/index. $\mathrm{php/products/product-pipeline/freeze-tolerant-eucalyptus].}$

10. Vaidyanathan G: Government approves GM trees;company plans for biofuel use. 2010 [http://www.eenews.net/climatewire/2010/05/17/3/]

11. Perkowski M: USDA plans to outsource biotech studies. 2011 [http://www. capitalpress.com/content/mp-biotech-process-041511].

\section{doi:10.1186/1753-6561-5-S7-061}

Cite this article as: Strauss and Viswanath: Field trials of GM trees in the USA: activity and regulatory developments. BMC Proceedings 20115 (Suppl 7):061.

\section{Submit your next manuscript to BioMed Central and take full advantage of:}

- Convenient online submission

- Thorough peer review

- No space constraints or color figure charges

- Immediate publication on acceptance

- Inclusion in PubMed, CAS, Scopus and Google Scholar

- Research which is freely available for redistribution

Submit your manuscript at www.biomedcentral.com/submit
C Biomed Central 